\title{
Diversity of mitochondrial DNA in fallow deer (Dama dama) from Brijuni National park, Croatia - short communication
}

\author{
Magda Sindičić 1 , Ira Topličanec ${ }^{2 *}$, Eduard Kolić ${ }^{3}$, Klara Marićc \\ Dean Konjevićs ${ }^{5}$ Alen Slavica ${ }^{1}$, and Zdravko Janicki ${ }^{1}$ \\ ${ }^{1}$ Department for Game and Wildlife, Faculty of Veterinary Medicine University of Zagreb, Zagreb, Croatia \\ ${ }^{2}$ Department of Veterinary Biology, Faculty of Veterinary Medicine University of Zagreb, Zagreb, Croatia \\ ${ }^{3}$ National park Brijuni, Fažana, Croatia \\ ${ }^{4}$ Dure Basaričeka 12, Zadar, Croatia \\ ${ }^{5}$ Department of Veterinary Economics and Epidemiology, Faculty of Veterinary Medicine University of \\ Zagreb, Zagreb, Croatia
}

SINDIČIĆ, M., I. TOPLIČANEC, E. KOLIĆ, K. MARIĆ, D. KONJEVIĆ, A. SLAVICA, Z. JANICKI: Diversity of mitochondrial DNA in fallow deer (Dama dama) from Brijuni National park, Croatia - short communication. Vet. arhiv 89, 895-902, 2019.

\section{ABSTRACT}

Fallow deer (Dama dama) are one of the most important game species in Europe and approximately 5 million animals are raised on farms globally. These deer are considered to be indigenous in Europe, but during the last ice age became extinct from most of their range except Sicily, the Balkan Peninsula and Anatolia. Research suggests that after the Middle Ages the indigenous population only survived in Anatolia (today's Turkey and Iran), so all present worldwide fallow deer populations were reintroduced from there. In Croatia, the species is mostly kept in fenced areas, while breeding in open hunting grounds or farms is rare. The goal of our research was to analyze the genetic diversity of fallow deer that live in the open grasslands of the Croatian island Veliki Brijun on an area of $5.72 \mathrm{~km}^{2}$. DNA was isolated from the muscle tissue of 22 animals and 405 base pairs of mitochondrial DNA control region were sequenced. One polymorphic site and two haplotypes were detected, both matching sequences from Germany, while one of the haplotypes was also previously detected in fallow deer in Hungary and Italy. The mtDNA diversity of Dama dama from Brijuni National park was rather low but, considering the island's isolation, the obtained results were in accordance with the diversity of previously researched European continental populations of fallow deer.

Key words: haplotype diversity; mitochondrial DNA; control region; island population; Dama dama

\footnotetext{
*Corresponding author:

Ira Topličanec DVM, Department of Veterinary Biology, Faculty of Veterinary Medicine University of Zagreb, Heinzelova 55, 10000 Zagreb, Phone: +385 12390 144; E-mail: ira.toplicanec@gmail.com
} 


\section{Introduction}

Fallow deer (Dama dama) became extinct from most of the European mainland during the last glacial period, and current knowledge suggests that the species survived the Pleistocene in only Sicily, the southern Balkan Peninsula and southern Anatolia (MASSETI, 1996). Today, it is believed that the indigenous populations of Sicily and Balkan Peninsula became extinct during the Middle Ages, and that the Anatolian population is the only indigenous fallow deer population that has survived until recent days, which is confirmed by archaeozoological evidence (MASSETI, 1996). Unlike many other temperate species after the last Ice Age, fallow deer did not naturally recolonize central and northern Europe, but the current distribution of European fallow deer is mostly influenced by human-mediated introductions (CHAPMAN and CHAPMAN, 1980). Records show that the spread of fallow deer began in the early Neolithic within Greece, and then increased in the Bronze Age, with translocations into the Western Mediterranean (YANNOULI and TRANTALIDOU, 1999). The Romans introduced fallow deer all over Europe, and many recent populations originate from reintroductions in the medieval period (SYKES et al., 2016). More recently, humans spread the species into the Near East, North and South America, northern and southern Africa, Australia, New Zealand and again widely across the Europe (CHAPMAN and CHAPMAN, 1980; ARSLANGÜNDOĜDU et al., 2010; KJELLANDER et al., 2012; CHAKANYA et al., 2016). Although fallow deer have prospered within much of their introduced range, numbers have dwindled within its postglacial native range of Turkey because of uncontrolled hunting (MASSETI, 2007; MASSETI and MERTZANIDOU, 2008; BAKER et al., 2017). The estimated global population of farmed fallow deer is close to 5 million, and New Zealand accounts for over one-half of the world's production of farmed deer (DASZKIEWICZ et al., 2015). In Europe, intensive farming prevails primarily because of the importance of fallow deer in the meat industry (CHAKANYA et al., 2016).

According to the hunting regulations in Croatia, fallow deer are listed as a game species and kept primarily in fenced areas, less on open hunting grounds and farms. One of the open areas where fallow deer are kept in Croatia is the Brijuni National Park. The park encompasses 14 islands, of which the largest is Veliki Brijun with an area of 5.72 $\mathrm{km}^{2}$, only $2 \mathrm{~km}$ away from the nearest land. Besides indigenous animals on open ground, numerous game and exotic species were introduced to the island as it was once used as a residence for the economic and political elite. Llamas (Lama gama), zebras (Equus quagga), zebu cattle (Bos taurus) and Asian elephants (Elephans maximus) were kept in a fenced "Safari Park" area and some of the offspring of these exotic animals still live within the Park today. Fallow deer, along with axis deer (Axis axis) and European mouflon (Ovis aries musimon) were first introduced to Veliki Brijun in around 1900 (FATOVIĆ FERENČIĆ, 2006; TRBOJEVIĆ VUKIČEVIĆ et al., 2012). Since then, fallow deer have 
lived on the Brijuni Island in specific conditions since there are no natural predators and their food is partly provided by humans (ROBIĆ et al., 2016). Individual animals have crossed the channel and colonized the mainland area of southern Istria, but there is no written evidence of return movement (SALAJ, 2000). Considering the isolation of the fallow deer population on the island, the genetic diversity of the population may easily be questioned, as there are no records of any subsequent introduction of new animals after 1900.

Previous research suggests low levels of mitochondrial diversity within most European fallow deer populations, with the exception of Italy and Rhodes (Greece). Although the Italian and Rhodes populations show higher levels of mitochondrial diversity, it is still considered low compared to the haplotype diversity in other deer species (BAKER et al., 2017). Also, high degree of differentiation between populations was found, especially among northern and southern ones reflecting the likelihood of glacial refugia (BAKER et al., 2017). This supports the assertion that the northern European populations (including central Europe) were created by the translocations of a few individuals from Turkey, and are affected by the genetic drift (BAKER et al., 2017).

The aim of this study was to analyze the genetic diversity of the fallow deer population from Brijuni National Park, Croatia. To date, there have been no studies published on the genetic diversity of the fallow deer population in Croatia, so this is the first research of that kind.

\section{Materials and methods}

DNA was extracted from the muscle tissue of 22 fallow deer individuals. Samples were collected in 2013 from animals culled as part of the regular population control activities implemented by the National Park service according to the "Wildlife Protection Program in Brijuni National Park" (JU NP BRIJUNI, 2013).

Genomic DNA was extracted $u$ sing the Wizard ${ }^{\circledR}$ Genomic DNA Purification Kit (Promega) following the manufacturer's protocol. The mitochondrial DNA (mtDNA) control region was amplified using primers DamaCtr1F (5'-ATTAATATAGCTCCATAAAAATCA) and DamaCtr1R (5'-AGGAAAGAACCA GATGTCTGATAA) (MASSETI et al., 2008). Polymerase chain reactions (PCR) were carried out in $20 \mu \mathrm{L}$, containing $150-250 \mathrm{ng}$ of DNA extract, 1,1 U of Platinum ${ }^{\circledR}$ Taq DNA Polymerase (Invitrogen), 1x PCR buffer, 0,2 $\mathrm{mM}$ dNTPs, $1,7 \mathrm{mM} \mathrm{MgCl}$ and $0,3 \mu \mathrm{M}$ of each primer. Reactions were performed in a Veriti 96-Well Thermal Cycler (Applied Biosystems) with an annealing temperature of 56 ${ }^{\circ} \mathrm{C}$ and 35 cycles. PCR products were purified and sequenced by the company Macrogen, Amsterdam, Europe.

Sequence alignment was performed using Clustal W (THOMPSON et al., 1994) implemented in BioEdit 7.2.5 (HALL, 1999) and sequences were manually edited. We 
used DnaSP 6.0 (ROZAS et al., 2017) to calculate the number of haplotypes, nucleotide diversity $(\pi)$, haplotype diversity $(\mathrm{h})$, and the average number of nucleotide differences (k) (TAJIMA, 1983).

\section{Results and discussion}

We analyzed 22 fallow deer mtDNA sequences in a total length of 405 base pairs (bp), corresponding to loci 15,486 - 15,890 of the entire fallow deer mtDNA sequence retrieved from the GenBank database (accession number JN632629, HASSANIN et al., 2012.). One polymorphic site was identified yielding two unique haplotypes, named DDC1 and DDC2 (Dama dama Croatia). The more frequent haplotype, DDC1, was detected in 14 samples (63.6\%), while the DDC2 haplotype was present in 8 samples $(36.4 \%)$. The haplotype diversity (h) of fallow deer from the island of Veliki Brijun was $0.485+/-0.064$, while the nucleotide diversity $(\pi)$ was 0.0012 and the average number of nucleotide differences $(\mathrm{k})$ was 0.485 .

Our data are accordant with studies on other European populations and depict low haplotype diversity similar to populations in Spain and Ireland, but they differ from the larger continental populations found in Germany, Hungary or Portugal (Table 1).

Table 1. Comparison of mtDNA sequence diversity for fallow deer samples from the island of Veliki Brijun, Brijuni National Park, Croatia (our study) and other European studies. N - number of samples, bp - length of analyzed mtDNA sequence in base pairs, $\mathrm{N} \mathrm{h}$ - number of haplotypes, $\mathrm{h}$ - haplotype diversity, $\pi$ - nucleotide diversity

\begin{tabular}{|l|c|c|c|c|c|c|}
\hline Author & Sample origin & $\mathrm{N}$ & $\mathrm{bp}$ & $\mathrm{N} \mathrm{h}$ & $\mathrm{h}$ & $\pi$ \\
\hline This study & Croatia, Brijuni NP & 22 & 405 & 2 & 0.485 & 0.0012 \\
\hline MASETI et al. (2007) & Turkey & 5 & 417 & 4 & 0.70 & 0.120 \\
\hline MASETI et al. (2007) & Rhodes, Greece & 13 & 417 & 8 & 0.86 & 0.057 \\
\hline MASETI et al. (2007) & Italy, Hungary, Greece & 19 & 417 & 11 & 0.89 & 0.099 \\
\hline LUDWIG et al. (2012) & German & 365 & 329 & 10 & $/$ & 0.095 \\
\hline BAKER et al. (2017) & Spain & 19 & 683 & 4 & 0.456 & 0.00069 \\
\hline BAKER et al. (2017) & Portugal & 17 & 683 & 3 & 0.647 & 0.00507 \\
\hline BAKER et al. (2017) & Italy & 30 & 683 & 7 & 0.731 & 0.01029 \\
\hline BAKER et al. (2017) & UK & 57 & 683 & 15 & 0.902 & 0.0031 \\
\hline BAKER et al. (2017) & Ireland & 16 & 683 & 4 & 0.442 & 0.00068 \\
\hline BAKER et al. (2017) & Hungary & 13 & 683 & 3 & 0.513 & 0.0008 \\
\hline BAKER et al. (2017) & Turkey & 20 & 683 & 2 & 0.1 & 0.00028 \\
\hline BAKER et al. (2017) & Bulgaria & 11 & 683 & 1 & 0 & 0 \\
\hline KUSZA et al. (2018) & Hungary & 41 & 450 & 3 & 0.678 & 0.003 \\
\hline
\end{tabular}


Nevertheless, it is difficult to interpret the results of genetic diversity and structure due to the lack of data about indigenous populations, and because of the numerous translocations from Turkey to Europe, and then among other European countries. Furthermore, breeding in closed populations and significant human impact also influence the genetic diversity.

We compared our results with $37 \mathrm{mtDNA}$ control region sequences from other European populations in a length of $329 \mathrm{bp}$. We found that our haplotype DDC1 matched sequences JN632629 (HASSANIN et al., 2012) and JF505624 (LUDWIG et al., 2012) from Germany, while our haplotype DDC2 matched the sequence JF505623, also from Germany (LUDWIG et al., 2012). The sequence JF505623 was the most common haplotype in Germany (LUDWIG et al., 2012) and it was also identified in Hungary and Italy (MASSETI et al., 2008). It is believed that a total of 15 mitochondrial haplotypes were introduced to Europe (LUDWIG et al., 2012). Phylogenetic analyses provided by KUSZA et al. (2018) revealed five distinct groups within world-wide fallow deer mtDNA sequences: (1) including fallow deer from Italy and Germany; (2) samples from Iberia (Spain and Portugal); (3) including Rhodian and a few Italian fallow deer; (4) sequences from Canada, Africa, the Middle East, and across Europe; and (5) including individuals from Anatolia (Turkey). A similar pattern in the phylogenetic analyses of fallow deer was previously reported by LUDWIG et al. (2012) and BAKER et al. (2017). LUDWIG et al. (2012) confirmed that the founder population of fallow deer in Germany had Turkish origins and, considering the same haplotypes were found in our study, we may also draw the same conclusion from our data. Unfortunately, there are no records about the number and origin of animals introduced to Veliki Brijun in the 1900s. Also, there are no records of any further introductions, except anecdotal testimonies about fallow deer that were brought to the island in the 1970s, again without any written record about the number or origin of the animals.

\section{References}

ARSLANGÜNDOĜDU, Z., M. KASPAREK, H. SARIBAŞAK, M. S. KAÇAR, O. YÖNTEM, M. TUĜRUL ŞAHIN (2010): Development of the population of the European Fallow Deer, Dama dama dama (Linnaeus, 1758), in Turkey (Mammalia: Cervidae). Zool. Middle East 49, 3-12. DOI: $10.1080 / 09397140.2010 .10638383$

BAKER, K. H., H. W. I. GRAY, V. RAMOVS, D. MERTZANIDOU, Ç. AKIN PEKŞEN, C. C. BILGIN, N. SYKES, A. R. HOELZEL (2017): Strong population structure in a species manipulated by humans since the Neolithic: the European fallow deer (Dama dama dama). Heredity 119, 16-26.

DOI:10.1038/hdy.2017.11

CHAKANYA, C., A. E. M. DOKORA, V. MUCHENJE, L. C. HOFFMAN (2016): The fallow deer (Dama spp.); endangered or not? . Zool. Garten N.F. 85, 160-172 (in German). 
CHAPMAN, N. G., D. I. CHAPMAN (1980): The distribution of fallow deer, a worldwide review. Mammal Rev. 10, 61-138.

DOI: $10.1111 / j .1365-2907.1980 . t b 00234 . x$

DASZKIEWICZ, T., N. HNATYK, D. DĄBROWSKI, P. JANISZEWSKI, A. GUGOLEK, D. KUBIAK, K. ŚMIECIŃSKA, R. WINARSKI, M. KOBA-KOWALCZYK (2015): A comparison of the quality of the Longisissimus luborum muscle from wild and farm raised fallow deer (Dama dama L.). Small Ruminant Res. 129, 77-83.

DOI: 10.1016/j.smallrumres.2015.05.003

FATOVIĆ-FERENČIĆ, S. (2006): Brijuni Archipelago: Story of Kupelwieser, Koch, and Cultivation of 14 Islands. Croat. Med. J. 47, 369-371.

HALL, T. A. (1999): BioEdit: a user-friendly biological sequence alignment editor and analysis program for Windows 95/97/NT. Nuc. Acid. Symp. Ser. 41, 95-98.

HASSANIN, A., F. DELSUC, A. ROPIQUET, C. HAMMER, B. JANSEN van VUUREN, C. MATTHEE, M. RUIZ-GARCIA, F. CATZEFLIS, V. ARESKOUG, T. T. NGUYEN, A. COULOUX (2012): Pattern and timing of diversification of Cetartiodactyla (Mammalia, Laurasiatheria), as revealed by a comprehensive analysis of mitochondrial genomes. C. R. Biol. 335, 32-50.

DOI: 10.1016/j.crvi.2011.11.002

JU NP BRIJUNI (2013): Wildlife Protection Program in Brijuni National Park. Ministarstvo zaštite okoliša i prostornog uređenja Republike Hrvatske, Zagreb, (in Croatian).

KJELlANDER, P., I. SVARTHOLM, U. A. BERGVALL, A. JARNEMO (2012): Habitat use, bedside selection and mortality rate of neonate fallow deer Dama dama. Wildl. Biol. 18, 280-291. DOI:10.2981/10-093

KUSZA, S., M. R. ASHRAFZADEH, B. TÓTH, A. JÁVOR (2018): Maternal genetic variation in the northeastern Hungarian fallow deer (Dama dama) population. Mamm. Biol. 93, 21-28.

LUDWIG, A., C. VERNESI, D. LIECKFELDT, E. Z. LATTENKAMP, A. WIETHÖLTER, W. LUTZ (2012): Origin and patterns of genetic diversity of German fallow deer as inferred from mitochondrial DNA. Eur. J. Wildl. Res. 58, 495-501.

DOI: $10.1007 / \mathrm{s} 10344-011-0571-5$

MASSETI, M., E. PECCHIOLI, C. VERNESI (2008): Phylogeography of the last surviving populations of Rhodian and Anatolian fallow deer (Dama dama dama L., 1758). Biol. J. Linn. Soc. 93, 835-844.

DOI: $10.1111 / \mathrm{j} .1095-8312.2007 .00951 . x$

MASSETI, M. (1996): The postglacial diffusion of the genus Dama Frisch, 1775, in the Mediterranean region. Suppl. alle Ricerche di Biol. della Selvag. 25, 7-29.

MASSETI, M. (2007): Island of deer. Deer 14, 36-41.

MASSETI, M, D. MERTZANIDOU (2008): Dama dama. The IUCN Red List of Threatened Species 2008, e.T42188A10656554. 
ROBIĆ, M., A. BECK, M. BELIĆ, R. TURK, B. ARTUKOVIĆ (2016): Histopathological changes in the abomasa of fallow deer from the Brijuni islands in Croatia - short communication. Vet. arhiv 86, 265-271.

ROZAS, J., A. FERRER-MATA, J. C SÁNCHEZ-DELBARRIO, S. GUIRAO-RICO, P. LIBRADO, S. E. RAMOS-ONSINS, A. SÁNCHEZ-GRACIA (2017): DnaSP 6: DNA Sequence Polymorphism Analysis of Large Datasets. Mol. Biol. Evol. 34, 3299-3302.

DOI: $10.1093 / \mathrm{molbev} / \mathrm{msx} 248$

SALAJ, M. (2000): Spatial plan of the National Park "Brijuni”. Ministarstvo zaštite okoliša I prostornog uređenja Republike Hrvatske, Zagreb. p. 61 (in Croatian).

SYKES, N. J., G. AYTON, F. BOWEN, K. BAKER, P. BAKER, R. CARDEN, C. DICKEN, J. EVANS, A. R. HOELZEL, T. F. G. HIGHAM, R. JONES, A. LAMB, R. LIDDIARD, R. MADGWICK, H. MILLER, C. RAINSFORD, P. SAWYER, R. THOMAS, C. WARD, F. WORLEY (2016): Wild to domestic and back again: the dynamics of fallow deer management in medieval England (c. $11^{\text {th }}-16^{\text {th }}$ century AD). Star 2, 113-116.

DOI: 10.1080/20548923.2016.1208027

TAJIMA, F. (1983): Evolutionary relationship of DNA sequences infinite populations. Genetics $105,437-460$.

THOMPSON, J. D., D. G. HIGGINS, T. J. GIBSON (1994): CLUSTAL W: improving the sensitivity of progressive multiple sequence alignment through sequence weighting, positionspecific gap penalties and weight matrix choice. Nucleic Acids Res. 22, 4673-4680.

TRBOJEVIĆ VUKIČEVIĆ, T., I. ALIĆ, A. SLAVICA, M. POLETTO, S. KUŽIR (2012): Preliminary osteometrical analysis of metapodium and acropodium bones of fallow deer (Dama dama L.) from the Brijuni Islands (Croatia). Vet. arhiv 82, 75-88.

YANNOULI, E., K. TRANTALIDOU (1999): The fallow deer (Dama dama Linnaeus, 1758): archaeological presence and representation in Greece. Conference Proceedings Archaologie in Eurasien; Holocene history of the European vertebrate fauna: modern aspects of research, 6-9 April, Berlin, Germany, pp. 247-282.

Received: 16 November 2018

Accepted: 23 January 2019

SINDIČIĆ, M., I. TOPLIČANEC, E. KOLIĆ, K. MARIĆ, D. KONJEVIĆ, A. SLAVICA, Z. JANICKI: Raznolikost mitohondrijske DNK jelena lopatara (Dama dama) iz Nacionalnog parka Brijuni, Republika Hrvatska - kratko priopćenje. Vet. arhiv 89, 895-902, 2019.

\section{SAŽETAK}

Jelen lopatar (Dama dama) jedna je od najvažnijih vrsta divljači u Europi, a na farmama diljem svijeta uzgaja se oko 5 milijuna ovih životinja. Smatra se da je vrsta autohtona u Europi, no tijekom posljednjeg ledenog doba izumrla je iz svih staništa osim Sicilije, Balkanskog poluotoka i Anatolije. Istraživanja pokazuju da je nakon srednjega vijeka autohtona populacija lopatara opstala samo u Anatoliji (današnja Turska i Iran) te da su sve današnje populacije reintroducirane iz tog područja. U Hrvatskoj je lopatar prisutan prije svega u gaterskim uzgojima, dok je slabije zastupljen u otvorenim lovištima i farmskom uzgoju. Cilj ovoga istraživanja bio je 
analizirati genetsku raznolikost slobodnoživuće populacije jelena lopatara na hrvatskom otoku Veliki Brijun, površine $5,72 \mathrm{~km}^{2}$. DNK je izolirana iz uzoraka mišićnog tkiva 22 različite životinje. Analizirani su sljedovi kontrolne regije mitohondrijske DNK ukupne dužine 405 parova baza te je utvrđeno jedno polimorfno mjesto koje definira dva haplotipa. Dobiveni sljedovi kontrolne regije mtDNK uspoređeni su s ostalim sljedovima pohranjenima u GenBank te su pronađene podudarnosti s uzorcima iz Njemačke kod oba haplotipa, a jedan se pojavljuje i u lopatara u Mađarskoj i Italiji. Raznolikost mtDNK jelena lopatara iz NP Brijuni prilično je niska, no s obzirom na otočnu izoliranost populacije takvi su rezultati u skladu s dosadašnjim istraživanjima europskih populacija jelena lopatara.

Ključne riječi: haplotipska raznolikost; mitohondrijska DNK; kontrolna regija; otočna populacija; Dama dama 